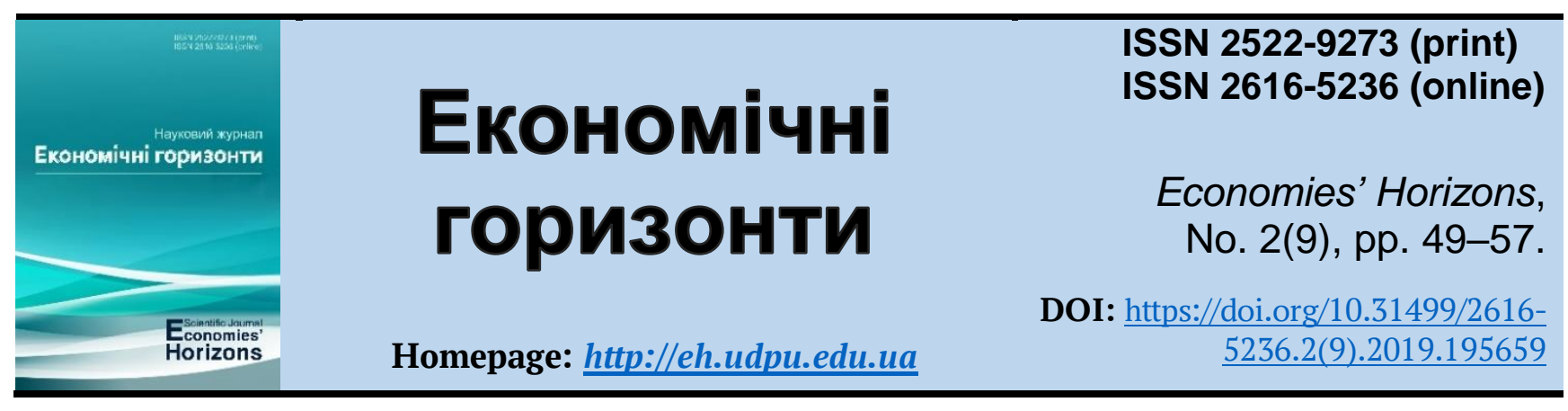

UDC 336.025:332.142.2

\title{
Methodical approach to the assessment of financial security of the region in the context of decentralization
}

\author{
Hanna V. Telnova ${ }^{1}$, Doc. Ec. Sc., Associate Professor \\ Bogdan Yu. Malovanyy ${ }^{2}$
}

Received: 21 April 2019

Accepted: 25 May 2019
Telnova, H. V. and Malovanyy, B. Yu. (2019), "Methodical approach to the assessment of financial security of the region in the context of decentralization", Economies' Horizons, no. 2(9), pp. 49-57, doi: https://doi.org/10.31499/2616-5236.2(9).2019.195659.

Abstract. The purpose of the research is to improve the methodological approach to assessing the financial security of the region in the context of decentralization, which, unlike the existing ones, makes it possible to determine the ways of ensuring the financial security of the regions through an integrated assessment of the contribution of individual factors and types of regulation to the final state of the financial security of the territories. Methodology. The methodological approach to the assessment of the financial security of the region under decentralization has been improved based on the application of normalization of the system of indicators and construction of integral indices by the type of impact indicator (exogenous or endogenous) and factors: decentralization, socio-economic status and fiscal policy of the regions. Individual time series have been identified and evaluated for each of these integrated indicators. Results. Based on the research, the methodological approach to the assessment of the financial security of the region under decentralization conditions has been improved, which makes it possible to determine the ways of ensuring the financial security of the regions by assessing the contribution of individual factors and types of regulation to the financial security. These individual contributions are grouped together to reflect the type of impact indicator (exogenous or endogenous) and factors such as decentralization, socio-economic status and fiscal policies of the regions. The categories of integrated indicators proposed in the article are useful for monitoring financial security drivers, making it clear what affects the financial security of a country under decentralization, how systemic events in the process of decentralization affect the financial security of regions over time. Practical meaning. The research identified three groups of regions of Ukraine in terms of their financial security: financially secure regions, which during the entire observation period were ascertained: a high integral financial security index (Dnipropetrovsk, Kyiv regions) and a sufficient integral financial security index (Lviv, Zaporizhzhya, Odesa, Poltava and Kharkiv regions); financially unstable regions where there is a potential for strengthening financial security (Vinnytsia, Donetsk, Kirovohrad, Mykolaiv, Cherkasy regions), but there is also a likelihood of aggravation of a negative financial situation (Ivano-Frankivsk, Zhytomyr, Sumy, Kherson, Khmelnytsky, Chernihiv regions); financially dangerous regions, which are dependent

\footnotetext{
${ }^{1}$ Donbass State Engineering Academy; Professor at the Department of Management; ORCID ID: https://orcid.org/0000-0002-5724-7229; e-mail: anntelnova2@gmail.com.

${ }^{2}$ Donbass State Engineering Academy; Postgraduate Student in the Department of Management; ORCID ID: https://orcid.org/0000-0001-8832-0030; e-mail: bogdan.malovanyy@gmail.com.
} 
on state support, are not able to independently fulfill the majority of delegated to the local level of authority and to finance the economic development of the region (Volyn, Luhansk, Transcarpathian, Rivne, Ternopil, Chernivtsi regions). Therefore, the advantage of using this system of integrated indicators is that they give the developers of national regional policy and internal regional policy an up-to-date picture of the financial security situation in the region, wider than that provided only by some unsystematic indicators. Prospects for further research. The prospect for further research should be to improve methodological support for the financial security of Ukrainian regions.

Keywords: methodological approach, assessment, financial security, region, decentralization, indicator, factor.

\title{
JEL Classification: C 43, G 28, H 39, H 70, H 72.
}

Number of references: 10; number of tables: 1; number of figures: 2; number of formulas: $\mathbf{0 .}$

\section{Методичний підхід до оцінки фінансової безпеки регіону в умовах децентралізації}

\author{
Ганна Володимирівна Тельнова ${ }^{1}$, д. е. н., доцент \\ Богдан Юрійович Мальований ${ }^{2}$
}

Стаття надійшла: 21.04.2019 Стаття прийнята: 25.05.2019
Telnova H. V., Malovanyy B. Yu. Methodical approach to the assessment of financial security of the region in the context of decentralization. Економічні горизонти. 2019. № 2(9). C. 49-57. DOI: 10.31499/2616-5236.2(9).2019.195659.

Анотація. Метою статті є удосконалення методичного підходу до оцінки фінансової безпеки регіону в умовах децентралізації, який, на відміну від існуючих, уможливлює визначення шляхів забезпечення фінансової безпеки регіонів через інтегральну оцінку внеску окремих факторів та типів регулювання у підсумковий стан фінансової безпеки територій. Meтоди. Удосконалено методичний підхід до оцінки фінансової безпеки регіону в умовах децентралізації на основі застосуванні нормалізації системи індикаторів та побудові інтегральних індексів за типом індикатора впливу (екзогенний або ендогенний) та факторів: децентралізації, соціально-економічного стану та фіскальної політики регіонів. Для кожного з цих інтегральних індикаторів були визначені та оцінені індивідуальні часові ряди. Результати. На підставі досліджень удосконалено методичний підхід до оцінки фінансової безпеки регіону в умовах децентралізації, який уможливлює визначення шляхів забезпечення фінансової безпеки регіонів через оцінку внеску окремих факторів та типів регулювання у фінансову безпеку. Ці індивідуальні внески зведені у групи, що відображають тип індикатора впливу (екзогенний або ендогенний) та фактори: децентралізації, соціально-економічного стану та фіскальної політики регіонів. Пропоновані у статті категорії інтегральних показників корисні для моніторингу драйверів фінансової безпеки, дозволяють зрозуміти, що впливає на фінансову безпеку країни в умовах децентралізації, як системні події у процесі децентралізації впливають на фінансову безпеку регіонів у часі. Практичне значення. В результаті досліджень виокремлено три групи регіонів України за рівнем їх фінансової безпеки: фінансово безпечні регіони, в яких протягом всього періоду спостереження констатувався: високий інтегральний індекс фінансової безпеки (Дніпропетровська, Київська області) та достатній інтегральний індекс фінансової безпеки (Львівська, Запорізька, Одеська, Полтавська та Харківська області); фінансово нестійкі регіони, в яких є потенціал украплення фінансової безпеки (Вінницька, Донецька, Кіровоградська, Миколаївська, Черкаська області), але й є ймовірність загострення негативної фінансової ситуації (Івано-Франківська, Житомирська, Сумська,

1 Донбаська державна машинобудівна академія; професор кафедри менеджменту; ідентифікатор ORCID: https://orcid.org/0000-0002-5724-7229; e-mail: anntelnova2@gmail.com.

2 Донбаська державна машинобудівна академія; аспірант кафедри менеджменту; ідентифікатор ORCID: https://orcid.org/0000-0001-8832-0030; e-mail: bogdan.malovanyy@gmail.com. 
Херсонська, Хмельницька, Чернігівська області); фінансово небезпечні регіони, які є залежними від державної підтримки, неспроможні самостійно виконувати більшість делегованих на місцевий рівень повноважень та фінансувати економічний розвиток регіону (Волинська, Луганська, Закарпатська, Рівненська, Тернопільська, Чернівецька області). Отже, перевагою застосування даної системи інтегральних індикаторів $\epsilon$ те, що вони надають розробникам державної регіональної політики та внутрішньої регіональної політики актуальну картину про стан фінансової безпеки в регіоні, ширшу, ніж та, яку надають лише окремі несистематизовані показники. Перспективи подальших досліджень. Перспективою подальших досліджень має стати удосконалення методичного забезпечення фінансової безпеки регіонів України.

Ключові слова: методичний підхід, оцінка, фінансова безпека, регіон, децентралізація, індикатор, фактор.

Кількість джсерел: 10; кількість таблиць: 1; кількість рисунків: 2; кількість формул: 0.

\section{Introduction.}

Changes in the general economic situation, mistakes in the policies of local governments can lead to systemic financial security risks, creating a dangerous situation for the country's financial system. The monitoring of these risks requires quantitative information covering these economic phenomena, as well as the development of financial policies of the state and regions, decentralization processes and its impact on the financial security of the regions. This information is indeed crucial for identifying the root cause of a potential or actual financial crisis, as well as for further evaluating and monitoring its possible effects. Obtaining the values of the financial security indicators of the regions on different aspects does not allow systematically assessing the comparative status of the regions due to the large volume of indicators, determine the directions of ensuring the financial security of the regions, their potential and the effectiveness of financial management in the region. Therefore, it is necessary to develop a methodological approach to assessing the financial security of the region in the context of decentralization, which would be able to meet these basic objectives.

\section{Literature review.}

The work of foreign scientists is devoted to regional financial stability (Afonso, 2013; Hendrick, 2014; Purbadharmaja, 2017). Unsystematic indicators of financial security of the region are presented in the works of
M. Medvid (2006; 2008), I. Chervyakov et al. (2009), V. Petrova and T. Pushkar (2012), T. Sukhorukova, O. Alexandrova and K. Savgira (2018). There are several approaches in the scientific literature of our country to formulate a methodological approach to assessing such indicators. S. Lelyuk proposes the stages of organization of the system of monitoring the financial security of regions (Lelyuk, 2014). M. Medvid develops "methodological approaches to assessing the state of financial security in the region, which consist in a consistent comparison of the system of financial security indicators with their thresholds in combination with the analysis of trends in these indicators" (Medvid, 2008). Identifying the systemic financial security risks of regions from partial indicators of the financial system is of paramount importance. Aggregated data are needed to recognize overall trends and overall financial security risks, while regional-level data are better informed about the concentration of risks. Therefore, given that the construction and interpretation of financial security indicators in a region is intended to provide a real summary assessment of its level, it is necessary to aggregate the information contained in a number of groups of indicators. The methodological guidelines for calculating the level of economic security of Ukraine include the stages of constructing an integrated assessment of economic security, which can also be applied to the financial 
security of regions (Ministry of Economic Development of Ukraine, 2013).

\section{Methodology.}

Research methods will be to apply the normalization of the indicator system and the construction of integral indices by the type of impact indicator (exogenous or endogenous) and factors: decentralization, socio-economic status and fiscal policy of the regions. Individual time series have been identified and evaluated for each of these integrated indicators.

\section{Research objectives.}

The purpose of the article is to improve the methodological approach to assessing the financial security of the region in the context of decentralization, which, unlike the existing ones, makes it possible to identify ways to ensure the financial security of the regions through an integrated assessment of the contribution of individual factors and types of regulation to the final state of financial security of the territories.

\section{Results and discussions.}

It is proposed to select indicators for integrated assessment by groups that reflect the factors and potential of financial security. For consistent comparability of indicators, they should be normalized across all regions of Ukraine and over the entire decentralization period, which will allow to take into account not only the spatial aspect (level of financial security by regions in a certain year), but also the change in the financial security of regions with the development of decentralization processes.

The normalization of stimulus and disincentive indicators for the financial security of the regions should be such that each of the indicators is in the range 0 to 1 , with the unit indicator equation corresponding to the maximum financial security of the region and zero to the worst.

Formula for normalization of disincentive indicators:

$$
x_{i}^{u c}=\frac{x_{i}-x_{\min }}{x_{\max }-x_{\min }}, i=\overline{1, n},
$$

where $n$ is the volume of statistics for each indicator.

The formula for the normalization of the disincentive indicators:

$$
x_{i}^{\mu \partial}=\frac{x_{\max }-x_{i}}{x_{\max }-x_{\min }}, i=\overline{1, n} .
$$

In the group "Exogenous indicators of institutional factors of decentralization" indicators-stimulators are: the share of regional budget revenue in consolidated budget revenues; share of local taxes and fees in regional budget revenues (excluding MBT); share of regional budget expenditures in consolidated budget expenditures; the share of expenditures financed from the revenues of the regional budget (excluding MBT). The disincentive indicator of this group: the share of transfers from the state budget in the structure of revenues of the regional budget.

In the group "Endogenous Indicators of Institutional Decentralization Factors", stimulus indicators are: the share of regional budget revenues (excluding MBT) in GRP; share of regional budget expenditures in GRP; local budget deficit (-) / surplus ratio (+); the share of (-) (surplus (+)) regional budget in GRP. The disincentive indicator of this group: subsidization of the regional economy.

In the group "Exogenous indicators of factors of socio-economic status of the region" indicators-stimulants are: comparative index of physical volume of GRP to GDP; share of the region's capital investments in the country's capital investments; the level of employed population of working age (according to ILO methodology). The disincentive indicators of this group: comparative index of consumer prices of the region; share of the region in the amount of wage arrears.

In the group "Endogenous indicators of factors of socio-economic status of the region" indicators-stimulators are: the index of physical volume of gross regional product; export index of products of the region; share of capital investments of the region in GRP; share of 
enterprises in the region that have made a net profit; index of real disposable income per capita. There are no disincentive indicators in this group.

In the group "Exogenous indicators of fiscal factors" indicators-stimulators are: the coefficient of tax independence; budget coverage ratio; coefficient of overall tax stability; the profitability factor of the revenue base. The disincentive indicator of this group: the share of transfers from the state budget to GRP.

In the group "Endogenous Fiscal Factors Indicators" the indicators-stimulants are: the coefficient of budgetary security of the population; coefficient of economic efficiency of the budget; financial performance ratio of the budget. The disincentive indicators of this group: share of crediting of the budget of the region in GRP; debt service ratio.

Symptoms of financial risk include:

- the negative impact of decentralization on the financial security of the regions;

- the negative impact of the socio-economic situation on the financial security of the region;

- the negative impact of fiscal policy, performance and productivity of local budgets on financial security.

Integral index indicators should reflect one or more of these danger symptoms in a timely manner. It is proposed to use the arithmetic mean method to calculate integral indices.

Determining the integrated indicators of indicators by groups of factors for all regions for each year shows a manifestation of the overall strengthening or weakening of the financial security of regions with a decentralization trend, that is, reflects the systemic financial security of the regions. Dynamic assessment is important for identifying the development of financial systems in the regions and justifying the right course in decentralization processes.

Determining integral indicators by groups of factors for each region provides summary data for assessing the impact of decentralization, socio-economic status of territories, and fiscal performance on financial security.

According to the calculations of integrated exogenous and endogenous indicators of institutional factors of decentralization, the most favorable institutional conditions for decentralization, formed at the state level, were reflected in the state of finances of Dnipropetrovsk, Kyiv, Odesa and Kharkiv regions. These regions have generated a significant amount of their own revenues, and have achieved the greatest independence of budgets. However, compared to the GRP of the mentioned regions, these funds are not sufficient. In Transcarpathian, Chernivtsi, and Rivne regions, most of the local budget revenues are distributed through GRPs, and their expenditures account for more than $30 \%$ of the regional product. Therefore, they are more resilient in domestic financial policies.

The final assessment of the institutional factors of decentralization made it possible to rank regions in terms of financial security. The least stable under decentralization conditions are Luhansk, Ivano-Frankivsk, Ternopil, Volyn region (the value of the integral index in 2017 is less than 0.5), and the most stable in Zaporizhzhya, Lviv, Kyiv, Kharkiv, Odesa and Dnipropetrovsk regions (values of the integral index in 2017 is more than 0.6).

The analysis of the integral values within the time series has allowed to establish the growth of positive influence on the financial security of the regions of Ukraine both in terms of state policy of decentralization and internal regional policy in conditions of decentralization. The latter is more effective, that is, local self-government bodies of the regions are fully aware of their role in ensuring the autonomy, capacity and self-sufficiency of regional development.

According to the normalized data of integral indicators of the factors of socio-economic status of the regions of Ukraine, the most favorable socio-economic situation in Dnipropetrovsk, Kyiv and Lviv regions. In these regions, economic development has been achieved at a high rate, provided with large 
volumes of investments, inflation processes are restrained, jobs are created and wages are paid in a timely manner.

At the same time, exclusively at the regional level, Khmelnitsk, Ternopil and IvanoFrankivsk regions are developing more dynamically than all other regions. So, according to the internal policy of regional development, they have a high potential for ensuring financial security.

The final assessment of the factors of the social and economic condition of the region made it possible to rank the regions in terms of financial security. The most rapidly developing are Dnipropetrovsk and Kyiv regions. They hold an effective concentration of capital, which allows providing an economic development. The obvious consequence of the post-conflict state is the low social and economic situation in Donetsk and Lugansk regions. It should be noted that while Lugansk region depends on state financial assistance, Donetsk region, having rather high budget indicators and the independence of local budgets, does not provide adequate funding for economic programs.

The analysis of the integral values of the financial security indicators of the regions according to social and economic status within the time series allowed establishing a significant increase in 2016-2017 years of a positive impact on the financial security of the regions of Ukraine's internal regional policy.

The calculated data of the integral indicators of fiscal factors made it possible to state that fiscal stability is observed in Dnipropetrovsk, Kyiv and Kharkiv regions. In these regions, high rates of sustainability of the income base and the tax base were achieved. Budget performance and efficiency indicators are the highest, except for those mentioned in Zaporizhzhya, Odesa and Poltava regions. These regions illustrate effective fiscal policy, budget planning, and local budget execution, allocating budget revenues to correct economic growth programs.

The final assessment of the fiscal factors of the region also allowed ranking the regions in terms of financial security. The most fiscally sustainable regions are Kharkiv, Zaporizhzhya, Poltava, Odessa, Dnipropetrovsk and Kyiv regions. They hold effective fiscal policy, effective administration of taxes, and budgetary support of the population. Low indicators of fiscal sustainability can be noted in Chernivtsi, Luhansk, Transcarpathian, Ternopil regions. The financial capacity of these regions is insufficient.

The analysis of the integral values of the fiscal security indicators of the regions according to a fiscal factor within the time series has allowed to establish an increase in a positive impact on the financial security of the regions of Ukraine of internal regional policy, while the state fiscal policy in 2015 and in 2017 had a negative impact on financial security.

Determining the integrated indicators according to the type of financial security impact for each region provides summary data for evaluating the performance of national regional and domestic financial security policies. The integral index for years, in this case, is designed to capture the systemic risk of financial risk arising from exogenous shocks or as a result of an inactive domestic regional policy. This method made it possible to determine that the most effective influence of state regional policy is observed in Dnipropetrovsk, Zaporizhzhya, Kyiv, Odesa and Kharkiv regions. At the same time, such a positive impact was observed throughout the observation period, in contrast to the effectiveness of internal regional policy, the positive effects of which have increased substantially in almost all regions of Ukraine only in 2016-2017 years. The exceptions are Donetsk and Lugansk regions, which must overcome the consequences of a military conflict.

The decisive influence of the internal regional policy on the financial security of the regions of Ukraine under the conditions of decentralization in 2017 year has been proved. At the same time, the existing principles of the state policy of regional development remain the most influential for the regions of Dnipropetrovsk and Kharkiv regions. The overall assessment of the financial security of the regions of Ukraine is given in Table 1. 
Telnova H. V., Malovanyy B. Yu. Methodical approach to the assessment of financial security of the region in the context of decentralization

\section{Table 1. The total integrated financial security indicators of the regions of Ukraine}

\begin{tabular}{|l|c|c|c|c|}
\hline \multicolumn{1}{|c|}{ Region } & $\mathbf{2 0 1 4}$ & $\mathbf{2 0 1 5}$ & $\mathbf{2 0 1 6}$ & $\mathbf{2 0 1 7}$ \\
\hline Vinnytsia & 0,47 & 0,52 & 0,58 & 0,58 \\
\hline Volyn & 0,37 & 0,44 & 0,49 & 0,52 \\
\hline Dnipropetrovsk & 0,68 & 0,68 & 0,71 & 0,75 \\
\hline Donetsk & 0,55 & 0,45 & 0,57 & 0,55 \\
\hline Zhytomyr & 0,43 & 0,45 & 0,52 & 0,55 \\
\hline Transcarpathian & 0,39 & 0,37 & 0,48 & 0,52 \\
\hline Zaporizhzhya & 0,56 & 0,58 & 0,65 & 0,65 \\
\hline Ivano-Frankivsk & 0,42 & 0,46 & 0,52 & 0,53 \\
\hline Kyiv & 0,59 & 0,61 & 0,70 & 0,73 \\
\hline Kirovohrad & 0,48 & 0,51 & 0,58 & 0,59 \\
\hline Lugansk & 0,48 & 0,44 & 0,53 & 0,43 \\
\hline Lviv & 0,48 & 0,53 & 0,61 & 0,64 \\
\hline Mykolaiv & 0,47 & 0,51 & 0,58 & 0,59 \\
\hline Odessa & 0,52 & 0,57 & 0,66 & 0,70 \\
\hline Poltava & 0,56 & 0,55 & 0,60 & 0,62 \\
\hline Rivne & 0,39 & 0,41 & 0,47 & 0,50 \\
\hline Sumy & 0,46 & 0,47 & 0,54 & 0,58 \\
\hline Ternopil & 0,38 & 0,42 & 0,48 & 0,52 \\
\hline Kharkiv & 0,52 & 0,56 & 0,61 & 0,64 \\
\hline Kherson & 0,42 & 0,45 & 0,52 & 0,55 \\
\hline Khmelnytsk & 0,44 & 0,48 & 0,55 & 0,58 \\
\hline Cherkasy & 0,47 & 0,51 & 0,58 & 0,58 \\
\hline Chernivtsi & 0,36 & 0,43 & 0,49 & 0,49 \\
\hline Chernihiv & 0,44 & 0,47 & 0,54 & 0,58 \\
\hline In Ukraine & 0,47 & 0,49 & 0,56 & 0,58 \\
\hline
\end{tabular}

The regions of Ukraine were grouped ac- the entire observation period using the cluster cording to their level of financial security for analysis tool (Fig. 1).

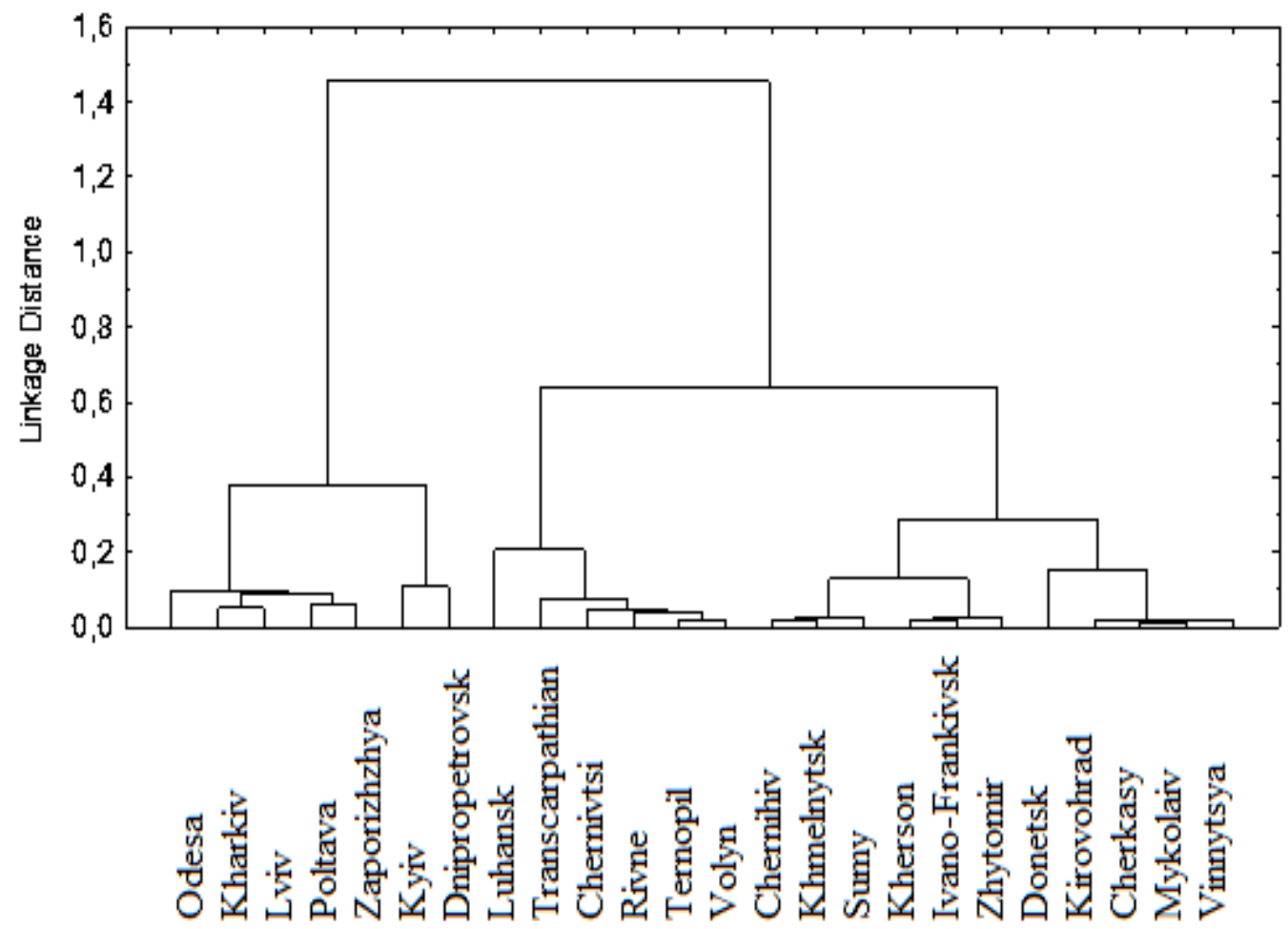

Fig. 1. Grouping of regions according to the level of financial security in 2014-2017 years 
As a result, three groups of regions are distinguished:

- financially secure regions in which, throughout the observation period, there was a high integrated financial security index (Dnipropetrovsk, Kyiv regions) and a sufficient integrated financial security index (Lviv, Zaporizhzhya, Odesa, Poltava and Kharkiv regions);

- financially unstable regions where there is a potential for strengthening financial security (Vinnytsia, Donetsk, Kirovohrad, Mykolaiv, Cherkasy regions), but there is also a likelihood of aggravation of a negative financial situation (Ivano-Frankivsk, Zhytomyr, Sumy, Kherson, Khmelnytsk, Chernihiv regions);

- financially dangerous regions, which are dependent on state support, are not able to fulfill independently the majority of delegated to the local level of authority and to finance the economic development of the region (Volyn, Luhansk, Transcarpathian, Rivne, Ternopil, Chernivtsi regions).

Generally, we propose a methodological approach to assessing the financial security of regions in Fig. 2.

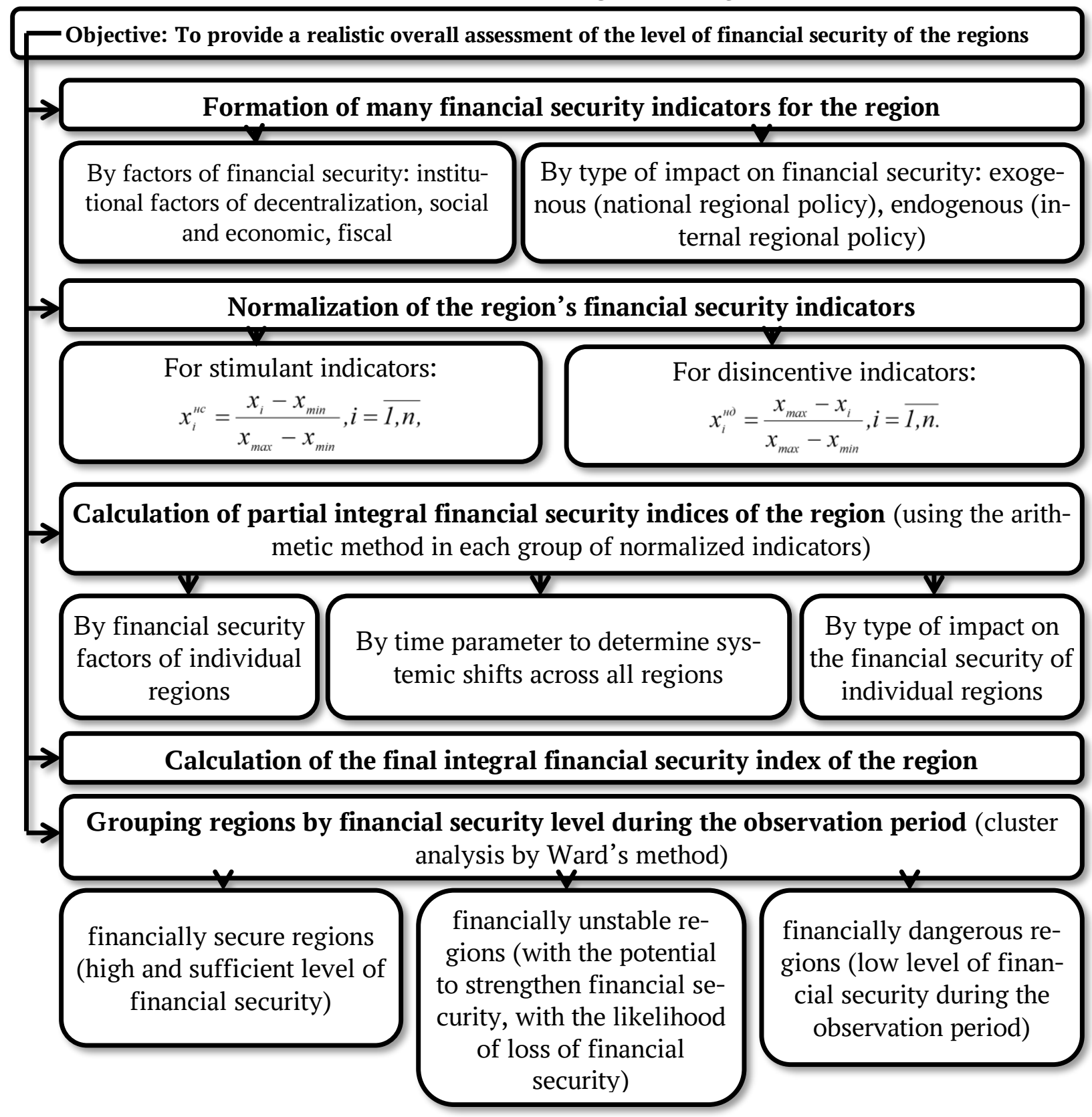

Fig. 2. A methodological approach to the assessment of the financial security of regions under decentralized conditions 


\section{Conclusions.}

Unlike other methodological approaches, the proposed one makes it possible to identify ways of ensuring the financial security of regions by assessing the contribution of individual factors and types of regulation to financial security. These individual contributions are grouped together to reflect the type of impact indicator (exogenous or endogenous) and factors such as decentralization, social and economic status and fiscal policies of the regions. Individual time series have been identified and evaluated for each of these integrated indicators. Such integrated metrics are useful for monitoring financial security drivers, making it clear what affects the country's financial security in a decentralized environment, how systemic events in the decentralization process affect the financial security of regions over time. Therefore, the advantage of using this system of integrated indicators is that they give the developers of national regional policy and internal regional policy an up-to-date picture of the financial security situation in the region, wider than that provided only by some unsystematic indicators.

\section{References}

Afonso, W. B. (2013), "Diversification toward stability? The effect of local sales taxes on own source revenue", Journal of Public Budgeting, Accounting and Financial Management, vol. 25, no. 4, pp. 649-674, doi: https://doi.org/10.1108/JPBAFM-25-04-2013-B004

Chervyakov, I. M., Ivashchenko, P. A. and Medvid, M. M. (2009), "Features of forecasting some indicators of financial security of the region", Bulletin of Kharkiv National University V. N. Karazin. Economic series, no. 869, pp. 137-143.

Hendrick, R. and Crawford, J. (2014), “Municipal fiscal policy space and fiscal structure: tools for managing spending volatility", Public Budgeting and Finance, vol. 34, no. 3, pp. 24-50, doi: https://doi.org/10.1111/pbaf.12042

Lelyuk, S. V. (2014), "Methodical approach to the organization of financial security monitoring of the administrative-territorial unit”, Business Inform, no. 2, pp. 99-104.

Medvid, M. M. (2006), “Determining the list of indicators for assessing the financial security of regions”, Culture of the Peoples of the Black Sea, no. 95, pp. 144-149.

Medvid, M. M. (2008), "Financial security of region in Ukraine (Kharkiv Oblast as a model)", Abstract of Ph.D. dissertation, Productive forces development and regional economy, Poltava National Technical University named after Yuriy Kondratyuk, Poltava, Ukraine.

Ministry of Economic Development and Trade of Ukraine (2013), Order "On approval of Methodological recommendations for calculating the level of economic security of Ukraine", available at: https://zakon.rada.gov.ua/rada/show/v1277731-13/sp:max25 (Accessed 21 March 2019)

Petrova, V. F. and Pushkar, T. A. (2012), "The financial security of the region as a prerequisite for sustainable socio-economic development", Management of Urban and Regional Development, pp. 82-85, available at: https://eprints.kname.edu.ua/29552/1/25.pdf (Accessed 21 March 2019)

Purbadharmaja, B. (2017), "The role of local government in budget allocation and management towards income distribution inequality and economic growth of regencies/city in Bali province”, IOSR Journal of Humanities and Social Science (IOSR-JHSS), vol. 22, no. 12, pp. 16-25.

Sukhorukova, T. G., Alexandrova, O. Y. and Savgira, K. D. (2018), "Estimation and directions of improvement of financial security of regions of Ukraine", Bulletin of Economics of Transport and Industry, no. 64, pp. 186-196.

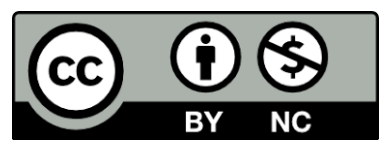

Цей твір ліцензовано на умовах Ліцензії Creative Commons «/з Зазначенням Авторства = Некомериійна 4.0 Міжнародна» (CC BY-NC 4.0). This is an open access journal and all published articles are licensed under a Creative Commons "Attribution-NonCommercial 4.0 International" (CC BY-NC 4.0). 